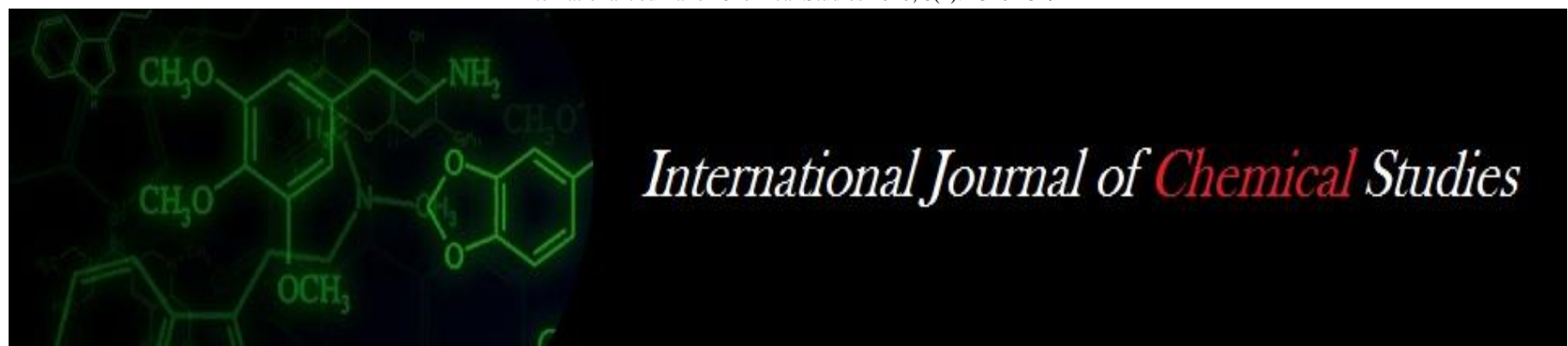

P-ISSN: 2349-8528

E-ISSN: 2321-4902

www.chemijournal.com

IJCS 2020; 8(2): 2326-2329

(C) 2020 IJCS

Received: 19-01-2020

Accepted: 21-02-2020

Vikas Tomar

Department of Agronomy

C S Azad University of

Agriculture and Technology,

Kanpur, Uttar Parades, India

Naushad Khan

Department of Agronomy

C S Azad University of

Agriculture and Technology,

Kanpur, Uttar Parades, India

Ravindra Tomer

Department of Agronomy

C S Azad University of

Agriculture and Technology,

Kanpur, Uttar Parades, India

Narinder Panotra

Sher-e-Kashmir University of

Agricultural Sciences

\&Technology of Jammu,

Jammu \& Kashmir, India

Corresponding Author:

Vikas Tomar

Department of Agronomy

C S Azad University of

Agriculture and Technology,

Kanpur, Uttar Parades, India

\section{Effect of chemical weed management and sowing method practices in late sown wheat (Triticum aestivum L.)}

\author{
Vikas Tomar, Naushad Khan, Ravindra Tomer and Narinder Panotra
}

DOI: https://doi.org/10.22271/chemi.2020.v8.i2ai.9096

\begin{abstract}
A field experiment was conducted during rabi seasons of 2015-16 and 2016-17 at Instructional Farm (SIF), Department of Agronomy, C S Azad University of Agriculture and Technology, Kanpur in alluvial tract of gangetic plains in Central part of Uttar Pradesh. The treatments consisted three sowing methods and five weed management practices. The experiment was laid out in split plot design with three replications. The results showed that plant height was increasing with increasing days after sowing in the relevant crop of wheat, respectively. The tallest plants were obtained in $S_{3}$ : Cross sowing followed by $S_{2}$ : Line sowing. The application of weed management practices on $\mathrm{W}_{4}$ : Two hand weeding (25 and 45 DAS) $\mathrm{W}_{2}$ : Clodinofop $\left(60 \mathrm{~g} \mathrm{ha}^{-1}\right) \mathrm{fb} 2,4-\mathrm{D}\left(500 \mathrm{~g} \mathrm{ha}^{-1}\right)$, significantly improved the growth and yields of Two hand weeding (25 and 45 DAS) followed by Clodinofop $\left(60 \mathrm{~g} \mathrm{ha}^{-1}\right) \mathrm{fb} 2,4-\mathrm{D}\left(500 \mathrm{~g} \mathrm{ha}^{-1}\right)$, amongst different cropping systems during the two years of experimentation.
\end{abstract}

Keywords: Sowing methods, weed management practices, plant height, yield, harvest index, B:C ratio

\section{Introduction}

Wheat (Triticum aestivum L.) is the second most important cereal crop next to rice and accounts for $36.2 \%$ of total food grain basket of the country. It is grown under diverse agro climatic conditions. The total area of wheat in the world is 221.12 million hectare with annual production of 697.8 million tonnes and productivity of $31.55 \mathrm{q} \mathrm{ha}^{-1}$. The largest producer of wheat in the world is the European Union followed by China, India and United States of America. The consumption of wheat in the world is 667 million tonnes but is kept satisfied with an equally high production figures. Consumption has been constantly increasing during the last 15 years with the increase in population and is prepared to shoot up further to 780 million tonnes in 2020. It has been estimated that India will need at least 109 million tonnes of wheat by 2020 as against present production of 93.5 million tonnes. The wheat production has increased manifold from 6.60 million tonnes at the time of independence to 97.44 million tons (Anonymous, 2017) ${ }^{[1]}$.

The productivity has witnessed an increase by 473 per cent i.e. from $670 \mathrm{~kg} \mathrm{ha}^{-1}$ to $3172 \mathrm{~kg} \mathrm{ha}$ 1 during the above period. Despite delayed sowing, the country recorded 30.71 million hectares. The clearly indicates the strength of systematic and planned wheat research in the country. It may be recalled that the total wheat production of the country during 1947-48 was just 5.6 million tons with average productivity of less than one $\mathrm{t} \mathrm{ha}^{-1}$. India has witnessed a record yield breaking increase in total wheat production i.e. 93.50 million tons from an area of $30.60 \mathrm{~m} \mathrm{ha}^{-1}$ with the productivity of $30.93 \mathrm{q} \mathrm{ha}^{-1}$ during $2015-16$. Out of total area of wheat in India, Uttar Pradesh alone contributes area 9.65 million hectare and production near about 26.87 million tons with productivity of $27.72 \mathrm{q} \mathrm{ha}^{-1}$. Wheat consumption in India estimated to surpass 110 million tons of wheat will be needed by 2020 .

Wheat is the backbone of food security of India. It is utilized for bread, cakes, cookies, noodles, petri-products and chapatti etc. Wheat grains contains starch $60-68 \%$, protein $8-15 \%$, fat $1.5-2.0 \%$, cellulose $2.0-2.5 \%$, and minerals $1.5-2.0 \%$ (Rathore, 2001) ${ }^{[6]}$. Wheat crop contributes substantially to the national food security by providing more than $50 \%$ of the calories to the people who mainly depend on it. The effects of weeds on wheat crop, the impact of weed competition on quantity and quality of wheat yield, allelopathic effects of 
certain weeds on crop growth and development and the poison effect of other weed species to humans and animals. Weeds usually found in wheat fields and associate with crop plants were identified and grouped based on their morphology. Studies on the determination of the critical weed-free period in wheat were reviewed and the importance of this period in weed management was discussed. Chemical and none-chemical weed control methods were reviewed. Certain agricultural and management practices aimed at promoting early canopy crop development and reduce weed growth are mentioned. Importance of plant factors, timing of farm operations, and selection of proper herbicide are discussed. Most recent research findings on weed management in wheat fields are incorporated. Herbicides recommended and practiced in wheat, their type, method of action, method and time of application, physiological effects on crop plants and weeds, and recent research findings on this aspect were included. Some suggestions and recommendations that sustain weed management and aimed at increasing crop productivity and minimizing weed effects are discussed Sharma \& Saroa, $2017^{[5]}$.

\section{Materials and Methods}

A field experiment was conducted during rabi seasons of 2014-15 and 2015-16 at Instructional Farm (SIF), Department of Agronomy, C S Azad University of Agriculture and Technology, Kanpur in alluvial tract of gangatic plains in Central part of Uttar Pradesh. The soil of the experimental field was sandy loam in texture and slightly calcareous having organic carbon $0.28 \%$, total nitrogen $0.032 \%$, available $\mathrm{P}_{2} \mathrm{O}_{5}$ $13.0 \mathrm{~kg} \mathrm{ha}^{-1}$, available $\mathrm{K}_{2} \mathrm{O} 180 \mathrm{~kg} \mathrm{ha}^{-1}, \mathrm{pH} 7.5$, electrical conductivity $0.20 \mathrm{dS} \mathrm{m} \mathrm{m}^{-1}$, wilting point $6.0 \%$, field capacity $19.2 \%$, water holding capacity $28.3 \%$, Bulk density $1.43 \mathrm{Mg}$ $\mathrm{m}^{-1}$, Particle density $2.60 \mathrm{Mg} \mathrm{m}^{-1}$ and porosity $45.6 \%$. The field experiment was conducted in Split plot design with three replications. keeping cropping systems in main plot and sub plot in subplots. A : Sowing methods (Main-plot) $\mathrm{S}_{1}$ : Broad cast sowing, $\mathrm{S}_{2}$ : Line sowing and $\mathrm{S}_{3}$ : Cross sowing $B$ : Weedmanagement practices (Sub-plot) $\mathrm{W}_{1}$ : Pendimethaline $(1 \mathrm{~kg}$ $\left.\mathrm{ha}^{-1}\right) \mathrm{fb}$ Sulfosulfuron $\left(25 \mathrm{~g} \mathrm{ha}^{-1}\right) \mathrm{W}_{2}$ : Clodinofop (60g ha $\left.\mathrm{g}^{-1}\right)$ fb 2,4-D (500g ha-1), W $\mathrm{W}_{3}$ : Pinoxaden $\left(50 \mathrm{~g} \mathrm{ha}^{-1}\right) \mathrm{fb}$ Carfentrazone $\left(30 \mathrm{~g} \mathrm{ha}^{-1}\right), \mathrm{W}_{4}$ : Two hand weeding (25 and 45 DAS) and $\mathrm{W}_{5}$ : Weedy check. Clean seed of wheat variety Halna-K7903 was sown at $20 \mathrm{~cm}$ rows distance at the sowing method of Line sowing, Cross sowing and Broad cast sowing seed rate with the help of seed drill. Crop was sown on December 15 and 17, during 2015 and 2016 growing seasons, respectively. Weeds were removed manually in two hand weeding at 25 and 45 days after sowing as per treatments during both years. Available moisture at sowing time up to $100 \mathrm{~cm}$ soil profile was measured which was 163.2 and 144.0 $\mathrm{mm}$. The amount and distribution of rainfall received during cropping season was 212.0 and $243.4 \mathrm{~mm}$ in $2014-15$ and 2015-16, respectively against the average annual rainfall of about $800 \mathrm{~mm}$. Recommended package of practices and fertilizers doses were applied in different treatments.

The cost of cultivation was calculated by taking in to account the prevailing prices of the input and application cost of the relevant treatments. Economics of different treatments was worked out to assess the most viable and remunerative water harvesting technique.

\section{Results and Discussion}

It is evident from the data that plant height of wheat was increasing with increasing DAS up to maturity (Table-1). The tallest plants were observed in $\mathrm{S}_{3}$ : Cross sowing followed by the treatment of $S_{2}$ : Line sowing. The lowest plant height was recorded under $S_{1}$ : Broad cast sowing during the two different years of study. Further, the application of weed management practices the plant height and tallest plants were found when $\mathrm{W}_{4}$ : Two hand weeding (25 and 45 DAS) was applied and minimum height was obtained from $\mathrm{W}_{5}$ : Weedy check when it was applied only through weed management practices has been also reported by Pal et al., (2012) ${ }^{[10]}$ and Chaudhary et al. (2016) ${ }^{[3]}$.

The seed yield of wheat under different treatments varied significantly and maximum values of these parameters in first and second year was $S_{3}$ : Cross sowing. The maximum yield of stover/straw yield was obtained from $\mathrm{S}_{3}$ : Cross sowing during two different years. Among weed management practices treatments highest seed yield was obtained from $\mathrm{W}_{4}$ : Two hand weeding (25 and $45 \mathrm{DAS}$ ) followed by $\mathrm{W}_{2}$ : Clodinofop $\left(60 \mathrm{~g} \mathrm{ha}^{-1}\right) \mathrm{fb} 2,4-\mathrm{D}\left(500 \mathrm{~g} \mathrm{ha}^{-1}\right)$ and lowest under $\mathrm{W}_{5}$ : Weedy check during both the years. Further, the combined effect of weed management practices was found to be significantly superior over sowing methods. The result indicate better growth in terms of seed yield, straw/stover yield in combined use supplemented with Two hand weeding (25 and 45 DAS). The harvest index did not showed significant variations during the two years of observation Kumar et al., (2012) ${ }^{[7]}$, Paighan et al., (2013) ${ }^{[9]}$ and Singh et al. $(2016)^{[3,4]}$

The maximum net return of $S_{3}$ : Cross sowing followed by $S_{2}$ : Line sowing under different treatments of sowing methods (Table-3). It may be attributed due to polled yield in different row crop adjustments during the two years of study. Subsequently, B:C ratio varied from $1.73,1.79 \& 1.76$ and $1.64,1.67 \& 1.65$ during the two years of experimentation, highest and lowest values were recorded in $\mathrm{S}_{3}$ : Cross sowing and $S_{1}$ : Broad cast sowing, respectively. The application of weed management practices further influenced the B:C ratio and values ranged from $1.73,1.76 \& 1.74$ and $1.64,1.66 \&$ 1.65 highest and lowest values were observed in $\mathrm{W}_{4}$ : Two hand weeding (25 and $45 \mathrm{DAS})$ and $\mathrm{W}_{1}$ : Pendimethaline ( $1 \mathrm{~kg}$ $\left.\mathrm{ha}^{-1}\right) \mathrm{fb}$ Sulfosulfuron $\left(25 \mathrm{~g} \mathrm{ha}^{-1}\right)$, respectively during the two different years Nizamani et al., (2014) ${ }^{[8]}$ and Anjum et al., $(2017)^{[2]}$. 
Table 1: Effect of plant height $(\mathrm{cm})$ under different treatments.

\begin{tabular}{|c|c|c|c|c|c|c|c|c|c|}
\hline \multirow{2}{*}{ Treatments } & \multicolumn{3}{|c|}{ Plant height $(\mathrm{cm}) 30$ DAS } & \multicolumn{3}{|c|}{ Plant height $(\mathrm{cm}) 60$ DAS } & \multicolumn{3}{|c|}{ Plant height (cm) 90 DAS } \\
\hline & 2015 & 2016 & Pooled & 2015 & 2016 & Pooled & 2015 & 2016 & Pooled \\
\hline \multicolumn{10}{|c|}{ A : Sowing methods } \\
\hline $\mathrm{S}_{1}$ & 7.65 & 7.91 & 7.78 & 47.68 & 49.26 & 48.47 & 82.44 & 84.94 & 83.69 \\
\hline $\mathrm{S}_{2}$ & 7.79 & 8.05 & 7.92 & 48.44 & 50.34 & 49.39 & 83.57 & 86.42 & 85.00 \\
\hline $\mathrm{S}_{3}$ & 7.92 & 8.21 & 8.06 & 50.32 & 52.11 & 51.21 & 86.70 & 89.84 & 88.27 \\
\hline SE (m) & 0.21 & 0.39 & 0.21 & 0.51 & 0.52 & 0.37 & 0.68 & 0.76 & 0.51 \\
\hline $\mathrm{CD}(\mathrm{P}=0.05)$ & N.S. & N.S. & 0.62 & 1.99 & 2.10 & 1.21 & 2.65 & 2.99 & 1.67 \\
\hline \multicolumn{10}{|c|}{ B : Weed management practices } \\
\hline $\mathrm{W}_{1}$ & 7.62 & 7.91 & 7.76 & 47.90 & 49.56 & 48.73 & 82.63 & 85.42 & 84.02 \\
\hline $\mathrm{W}_{2}$ & 7.96 & 8.23 & 8.10 & 49.92 & 51.59 & 50.75 & 86.08 & 88.92 & 87.50 \\
\hline $\mathrm{W}_{3}$ & 7.82 & 8.09 & 7.96 & 49.04 & 50.74 & 49.89 & 84.57 & 87.49 & 86.03 \\
\hline $\mathrm{W}_{4}$ & 8.35 & 8.62 & 8.48 & 52.15 & 54.04 & 53.10 & 89.82 & 93.18 & 91.50 \\
\hline $\mathrm{W}_{5}$ & 7.19 & 7.43 & 7.31 & 45.07 & 46.92 & 45.99 & 78.09 & 80.33 & 79.21 \\
\hline $\mathrm{SE}(\mathrm{m})$ & 0.28 & 0.31 & 0.18 & 0.56 & 0.54 & 0.39 & 1.00 & 1.17 & 0.77 \\
\hline $\mathrm{CD}(\mathrm{P}=0.05)$ & N.S. & N.S. & N.S. & 1.63 & 1.57 & 1.16 & 2.92 & 3.40 & 2.29 \\
\hline
\end{tabular}

Table 2: Effect of Grain Yield ( $\left.\mathrm{q} \mathrm{ha}^{-1}\right)$, Straw Yield $\left(\mathrm{q} \mathrm{ha} \mathrm{a}^{-1}\right)$ and Biological Yield $\left(\mathrm{q} \mathrm{ha}^{-1}\right)$ under different treatments.

\begin{tabular}{|c|c|c|c|c|c|c|c|c|c|}
\hline \multirow[b]{2}{*}{ Treatments } & \multicolumn{3}{|c|}{ Grain Yield $\left(q\right.$ ha $\left.^{-1}\right)$} & \multicolumn{3}{|c|}{ Straw Yield $\left(q\right.$ ha $\left.^{-1}\right)$} & \multicolumn{3}{|c|}{ Biological Yield $\left(q h^{-1}\right)$} \\
\hline & 2015 & 2016 & Pooled & 2015 & 2016 & Pooled & 2015 & 2016 & Pooled \\
\hline \multicolumn{10}{|c|}{ A : Sowing methods } \\
\hline $\mathbf{S}_{1}$ & 24.58 & 26.17 & 25.43 & 44.31 & 45.67 & 44.99 & 68.88 & 70.86 & 69.87 \\
\hline $\mathbf{S}_{2}$ & 24.98 & 26.29 & 25.58 & 44.72 & 45.84 & 45.28 & 69.36 & 71.94 & 70.65 \\
\hline $\mathbf{S}_{3}$ & 26.42 & 27.40 & 26.91 & 46.20 & 47.19 & 46.70 & 72.66 & 74.54 & 73.60 \\
\hline $\mathrm{SE}(\mathrm{m})$ & 0.40 & 0.23 & 0.18 & 0.30 & 0.31 & 0.22 & 0.52 & 0.58 & 0.39 \\
\hline $\mathrm{CD}(\mathrm{P}=0.05)$ & 1.33 & 0.89 & 0.60 & 1.17 & 1.21 & 0.69 & 2.04 & 2.25 & 1.24 \\
\hline \multicolumn{10}{|c|}{ B : Weed management practices } \\
\hline $\mathrm{W}_{1}$ & 24.88 & 25.83 & 25.36 & 45.21 & 46.31 & 45.76 & 70.11 & 72.09 & 71.10 \\
\hline $\mathrm{W}_{2}$ & 26.14 & 27.82 & 26.65 & 45.31 & 46.65 & 45.93 & 71.11 & 73.53 & 72.49 \\
\hline $\mathrm{W}_{3}$ & 25.19 & 27.15 & 26.50 & 45.21 & 46.53 & 45.92 & 69.84 & 72.75 & 71.29 \\
\hline $\mathrm{W}_{4}$ & 27.84 & 28.90 & 28.37 & 46.90 & 48.05 & 47.46 & 74.74 & 76.91 & 75.82 \\
\hline $\mathrm{W}_{5}$ & 22.58 & 23.40 & 22.99 & 42.77 & 43.62 & 43.19 & 65.36 & 66.96 & 66.16 \\
\hline SE (m) & 0.28 & 0.26 & 0.19 & 0.24 & 0.31 & 0.20 & 0.56 & 0.56 & 0.39 \\
\hline $\mathrm{CD}(\mathrm{P}=0.05)$ & 0.82 & 0.76 & 0.55 & 0.71 & 0.89 & 0.22 & 1.62 & 1.62 & 1.12 \\
\hline
\end{tabular}

Table 3: Effect of Cost of Cultivation (Rs ha $\left.{ }^{-1}\right)$, Gross Return $\left(\mathrm{Rs} \mathrm{ha}^{-1}\right)$, Net Return (Rs ha $\left.{ }^{-1}\right)$ and B:C Ratio under different treatments.

\begin{tabular}{|c|c|c|c|c|c|c|c|c|c|c|c|c|}
\hline \multirow{2}{*}{ Treatments } & \multicolumn{3}{|c|}{$\begin{array}{c}\text { Cost of Cultivation } \\
\left(\mathrm{Rs} \mathrm{ha}^{-1}\right)\end{array}$} & \multicolumn{3}{|c|}{ Gross Return ( Rs ha $\left.^{-1}\right)$} & \multicolumn{3}{|c|}{ Net Return $\left(\right.$ Rs ha $\left.^{-1}\right)$} & \multicolumn{3}{|c|}{ B:C Ratio } \\
\hline & 2015 & 2016 & Pooled & 2015 & 2016 & Pooled & 2015 & 2016 & Pooled & 2015 & 2016 & Pooled \\
\hline \multicolumn{13}{|c|}{ A : Sowing methods } \\
\hline $\mathrm{S}_{1}$ & 35891 & 37291 & 36591 & 59560.4 & 62234.4 & 60897.4 & 23269.4 & 23326.73 & 23298.07 & 1.64 & 1.67 & 1.65 \\
\hline $\mathrm{S}_{2}$ & 36291 & 37091 & 36691 & 59783.4 & 62384.4 & 61084.4 & 23492.4 & 23792.4 & 23642.4 & 1.65 & 1.68 & 1.66 \\
\hline $\mathrm{S}_{3}$ & 36591 & 36891 & 36741 & 62803.87 & 64879.2 & 63841.5 & 25512.2 & 26512.2 & 26012.2 & 1.73 & 1.79 & 1.76 \\
\hline $\mathrm{SE}(\mathrm{m})$ & - & - & - & 553.52 & 526.98 & 382.13 & 421.38 & 413.9 & 324.41 & 0.01 & 0.02 & 0.01 \\
\hline $\mathrm{CD}(\mathrm{P}=0.05)$ & - & - & - & 2161.13 & 2057.52 & 1246 & 1645.22 & 1616.02 & 1057.8 & 0.03 & 0.07 & 0.03 \\
\hline \multicolumn{13}{|c|}{ B : Weed management practices } \\
\hline $\mathrm{W}_{1}$ & 35150 & 35816 & 35483 & 59737.33 & 61925 & 60831.2 & 24587.33 & 25064 & 24825.67 & 1.64 & 1.66 & 1.65 \\
\hline $\mathrm{W}_{2}$ & 36015 & 37015 & 36515 & 62014.00 & 65306 & 63660 & 25612 & 25912 & 25762 & 1.71 & 1.74 & 1.72 \\
\hline $\mathrm{W}_{3}$ & 35905 & 36905 & 36405 & 61463.33 & 64207 & 62835.2 & 25448.33 & 25115 & 25281.67 & 1.70 & 1.73 & 1.71 \\
\hline $\mathrm{W}_{4}$ & 39935 & 40935 & 40435 & 65547.00 & 67826.33 & 66686.7 & 26109 & 26505.67 & 26307.34 & 1.73 & 1.76 & 1.74 \\
\hline $\mathrm{W}_{5}$ & 34450 & 34783 & 34617 & 54817.78 & 56567.33 & 55692.6 & 20366.67 & 19922.22 & 20144.44 & 1.59 & 1.63 & 1.61 \\
\hline SE (m) & - & - & - & 703.57 & 461.02 & 420.49 & 510.08 & 594.78 & 219.07 & 0.02 & 0.02 & 0.01 \\
\hline $\mathrm{CD}(\mathrm{P}=0.05)$ & - & - & - & 2054.12 & 1345.97 & 1195.68 & 1736.51 & 1736.51 & 622.93 & 0.05 & 0.07 & 0.03 \\
\hline
\end{tabular}

\section{Conclusion}

Based on two years of experiment it may be inferred that $S_{3}$ : Cross sowing supplemented with $\mathrm{W}_{4}$ : Two hand weeding (25 and 45 DAS) in soil showed good potential for sustainable production and proved to be quite remunerative in irrigated alluvial tract of Uttar Pradesh.

\section{References}

1. Anonymous. Agriculture statics at a glance in India, 2017.

2. Anjum SA, Ehsanullah U, Mohsin T, Rafi QIK. Morphological and phonological attributed of chickpea affected by different tillage practices and varied sowing method. American Journal of Plant Sciences. 2017; 7(4):1182-1187.

3. Chaudhary, Rampratap, Singh Harphool, Singh Maa. Project of wheat production under moisture condition of North- western India. Harayana Journal of Ecology. 2016; 3(5):234-242.

4. Singh Ranveer, Nath YN, Singh SK, Mohan TK, Shahi JP. Effect of agronomic management practices on growth, yield and quality of wheat under excessive moisture condition. Crop Research. 2016; 23(6):402408. 
5. Sharma S, Saroa GS. Effect of organic and integrated nutrient management practices on soil phosphorus fractions and total phosphorus in basmati-wheat sequence. Journal of soil and water conservation. 2017; 16 (11):79-85.

6. Rathore AL. Studies on nitrogen and irrigation requirement of late sown wheat. Indian Journal of Agronomy. 2001; 46(4):659-664.

7. Kumar S, Singh R, Shyam R, Singh VK. Weed dynamics, nutrient removal and yield of wheat as influenced by weed management practices under vally conditions of Uttarakhand. Indian Journal of weed science. 2012; 44(2):110-114.

8. Nizamani GS, Tunio S, Buriro UA, Keerio MI. Influence of different seed rates on yield contributing traits in wheat varieties. Journal of Plant Science. 2014; 2(5):232236.

9. Paighan VB, Gore AK, Chavan AS. Effect of new herbicides on growth and yield of wheat. Indian Journal of weed science. 2013; 45(4):291-293.

10. Pal S, Sharma R, Sharma HB, Pankaj. Bioefficacy and selectivity of different herbicides for weed control in wheat. International Agronomy Congress. 2012; 2:48-49 